\title{
Intraspecific Hybridization of Clarias anguilaris and Exotic Hollandis Clarias gariepinus
}

\author{
Adene I.C1 , Adedeji O.A1, Bakry H.01
}

${ }^{1}$ College of Agricultural Sciences Joseph Ayo Babalola University, Ikeji-Arakeji,Osun State Nigeria.

\begin{abstract}
Intraspecific hybridization work was carried out on Clarias anguilaris and exotic hollandis Clarias gariepinus with the aim of determining the combination with the best hatchability, survival, and growth performance. The highest percentage hatchability $(52.94 \%)$ was recorded for the parental exotic Clarias gariepinus while the least $(43.99 \%)$ was recorded for the parental Clarias anguilaris, $51.80 \%$ hatchability was recorded for female Clarias anguilaris x male exotic Clarias gariepinus and $50.68 \%$ hatchability for female exotic Clarias gariepinus x male Clarias anguilaris respectively. The highest percentage survival of $74.5 \%$ was recorded for parental Clarias anguilaris and the least percentage survival of $38 \%$ was recorded for parental exotic Clarias gariepinus. The highest growth performance of $1.77 \mathrm{~g}$ was observed in pure exotic hollandis $\mathrm{C}$.gariepinus fry, followed by the hybrid cross of female exotic Clarias gariepinus x male Clarias anguilaris $(1.60 \mathrm{~g})$, then the hybrid cross of male exotic Clarias gariepinus $\mathrm{x}$ female Clarias anguilaris $(1.53 \mathrm{~g})$ and the least was $1.43 \mathrm{~g}$ for pure Clarias angularis fry. The highest length increase of $0.89 \mathrm{~cm}$ was observed in the fry of pure exotic hollandis Clarias gariepinus and the least is $0.53 \mathrm{~cm}$ for pure Clarias angularis fry. Therefore the result of this research work shows that the hybrid of Male exotic holladis Clarias gariepinus x Female Clarias anguilaris is better for culture since the percentage survival, hatchability and length increase is higher than that of Female exotic Clarias gariepinus x Male Clarias anguilaris. Although there was no significant difference in their growth performance.
\end{abstract}

Keywords: Intraspecific, Hybridization, Clarias, Exotic, Hatchability, Survival, Growth

\section{INTRODUCTION}

The demand for high quality protein especially from aquatic source is rising dramatically due to global population expansion hence increased aquacultural production is clearly needed to meet this demand. In the third millennium, because capture fisheries are at capacity or showing precipitous declines due to over fishing, habitat destruction and increasing population, increase in capture fisheries are not anticipated under the current global condition (Dunham et al, 2001), especially when the estimated daily minimum crude protein requirement of an adult in Nigeria varies between 65 and $85 \mathrm{~g}$ per person, and it is recommended that $35 \mathrm{~g}$ of this minimum requirement is expected to be obtained from animal products (Oloyede, 2005).

Encouraging and improving fish production genetically and taking the advantage of its prolificacy and short period of its age at maturity, will in no doubt increase accessibility to animal protein, to meet the expected minimum requirement. The usual traditional method of growing genetically improved fishes has been through hybridization and selective breeding. In selection, the target could be based on quantitative or qualitative trait. Therefore there is the need to boost its fingerlings production and increase its growth performance. One of the current methods of improving growth performance of aquaculture species is through biotechnology manipulation. This could be through hybridization chromosome manipulation etc. (Olufeagba, 1997).

Hybridization can be defined as the union of gametes from two different species strains to produce new organisms of desirable characteristic with the aim of improving the genetic quality of the offspring (hybrid) as compared with those of parental stock.

Generally, hybridization has been found to be a breeding program that involves mating combination

This article is published under the terms of the Creative Commons Attribution License 4.0

Author(s) retain the copyright of this article. Publication rights with Alkhaer Publications.

Published at: http://www.ijsciences.com/pub/issue/2017-08/

DOI: 10.18483/ijSci.1292; Online ISSN: 2305-3925; Print ISSN: 2410-4477 
between different populations of fish which produce superior offspring with hybrid vigor for grow-out (Taye, 1993). Hybridization posses two important advantages; it prevent in- breeding and assist in disease resistant strain (Worforth, 1994). The detrimental effects of breeding are well documented and can result in decrease by about 30 percent or greater in growth production, survival and reproduction (Dunham, 2001). Hybrid line can only be maintained by using the parental line for mating, since genetic uniformity and extreme heterozygosity of hybrid is lost after a single generation or random mating (Seagrant, 1987).

Hybrids are progeny of parents from species of genus either by interspecific, intraspecific or intrageneric crossing. Fast growing species obtained from the act of crossing are often cherished by most farmers. Interspecific hybrid will be generated when parents from two different genus are crossed. Interpecific hybrids are often sterile and usually do not display hybrid vigor. Intraspecific hybridization is the crossing or mating of fish of the same species and genus but from different locality, region or ecological zones. The motive behind this is to get an improved quality fish. The primary goal of intraspecific hybridization is to produce hybrids from species of different genotypes exclusively for production. The species used for crossing should be of pure line so that the generation of hybrids can produce quality and fast growing offspring. Bondary, (1984) affirmed that hybrids from intraspecific hybridization are superior in growth, food conversion, resistant to disease, reproductive ability and meat quality resulting in improved viability. Fish breeding has had minimum impact on improving productivity in the fish farming industry and therefore it is important that fish farmers have a good grasp of genetic and breeding principles because they are among the major factors that govern productivity (Madu and Aluko, 1999).

The Clariid catfishes, order siluriformes are distributed in Africa, Asia Minor and South-east Asia and the Indian subcontinent (Teugels and Adriaens, 2003). Two genera of this family, clarias and heterobranchus, with the cichlids are mostly used in African aquaculture (Agnese et al., 1995). Clariid catfish exhibit many qualities which make them suitable for aquaculture this include ability to withstand stress, disease resistance, fast growth, high yield potential, high fecundity as well as good palatability. The fishes also exhibit fast growth in various culture systems, hence their importance in aquaculture. In addition, catfishes can withstand low dissolved oxygen and $\mathrm{PH}$ levels, and can grow on a wide range of natural and low cost artificial feeds (Hulsman and Ricer, 1987).
Clariid catfishes have gained prominence as important food fish species for aquaculture. They are found in South-East Asia and in Africa. The highest generic diversity is found in African continent where about 14 genera have been found (Tuegel, 1986a) against two in South-East Asia. The species of these fish are very popular with aquaculturist and consumers alike and as such commands a very good commercial value in the market. They are cultured primarily in freshwater ponds in tropical countries where they are widely found (Venden Bossiches and Bernacsek, 1990).

Angularis and exotic Clarias gariepinus of catfish have been observed to be of high economic value, fast growing and high survival performance. However, fingerlings of Angularis species do not grow as fast as those of the exotic species which have undergone genetic improvement like selective breeding program in which the breeder choose the next generation's brood stock, based on some predetermined criteria. Selective breeding has been used to improve various characteristics of farmed species ranging from weight, resistance to disease, environmental variability, survival, increase fecundity, fry survival and ability to withstand adverse environmental conditions (Dunhan and Smitherman, 1987).

\section{Justification}

The growth performance, survival of young fishes and the genetic quality has been a great challenge to commercial fish farmers which has hindered the high production of fingerlings . It is therefore imperative to determine the genetic or biotechnological knowledge in finding a lasting solution to the problem of high mortality in young fish and stunt growth rate which lead commercial fish farmer to an endless fish loss. Hence the cross between Angularis and Exotic clarias to produce a hybrid that combines the good qualities of the two, especially that of improved variety to solve the problem faced by the farmers.

\begin{abstract}
Aims and Objectives
To determine the hatchability and survival rate of clarias angularis, Exotic Hollandis clarias gariepinus and their reciprocal crosses.

To compare the growth performance of the two strains of clarias angularis, Exotic Hollandis Clarias gariepinus and their reciprocal crosses.
\end{abstract}

\section{Materials and Method}

\section{Research Site}

This research was carried out at the Fish Experimental Hatchery Laboratory, College of 
Agricultural Sciences, Joseph Ayo Babalola University, Ikeji-Arakeji, in Oriade Local Government Area (LGA) of Osun State, in South Western Nigeria, West Africa. The Local Government has an area of about $465 \mathrm{~km}^{2}$ with population of 148,617 (Andrade-Neto et al 2003). It is predominantly occupied by Ijesa people - a Yoruba tribe in Nigeria. Its capital is Ijebu -Jesa (or Ijebu Ijesha), in the North of the area at $7^{0} 41^{\prime} 00^{\prime \prime} \mathrm{N}$ $4^{0} 49^{\prime} 00^{\prime \prime} \mathrm{E} / 7.68333^{\circ} \mathrm{N} 4.81667^{\circ} \mathrm{E}$. It is situated in the Tropical rain Forest zone, with scattered swamps, rivers, waterfall and water springs in Erin Ijesa, a town in the Local Government which serves as a Tourist center. The soil is fertile and encourages cultivation of various type of food and industrial crops (Zegarac, 2004)

\section{Source of Breeders}

Brood stocks of Clarias angularis (Two males and Two Females) were collected from mashopa farms, Low Cost Housing Estate beside Co-operative House, New Ife Road Ibadan while the exotic Hollandis Clarias garieoinus(Two Males and Two Females) were collected from premium ranch and fisheries venture, $\mathrm{k} / \mathrm{m} 5$, Iresapa road Ogbomoso, both in Oyo State, Nigeria.

\section{Broodstock Selection}

The mature females were selected based on their swollen, reddish vent, well distended soft abdomen and extraction of few eggs on gentle running of finger on the abdomen. Ripe male were also selected base on their reddish urino-genital papillae.

\section{Hormone Injection}

The fish were sexed into male and female and kept separately in four labeled plastic bowls containing water and were covered with chicken mesh and heavy weight place on it so that the fish will not jump out. The male and females of each were weighed and the female injected with synthetic hormone (Ovaprim). This was administered intraperitoneal (i.e just under the pectoral fin) at the rate of $0.5 \mathrm{ml}$ per kilogram of fish.

\section{Milt and Eggs Collection}

After the latency period of 12 hours, the milt was collected by sacrificing the male, the two testes were removed, well cleaned and placed in a label Petridish for weighing and measurement. Also the females were equally cleaned with water and then handstriped by gently pressing the abdomen with finger and the eggs collected in a dry labeled Petri-dish.

\section{Artificial Fertilization}

The testes were cut opened using razor blade and the milt was released on the eggs for fertilization. Saline solution of $0.9 \%$ sodium chloride $(\mathrm{Nacl})$ was added to facilitate the fertilization. A plastic spoon was used to mix the eggs and milt thoroughly to ensure proper fertilization.

\section{Experimental Crosses}

The following genetic combinations were carried out.

\section{Parental Crosses}

$\begin{array}{lll}\text { Female } & & \text { Male } \\ \text { Clarias anguilaris } & \text { x } & \text { Clarias anguilaris } \\ \text { Exotic Hollandis clarias gariepinus } & \text { x } & \text { Exotic Clarias gariepinus }\end{array}$

\begin{tabular}{|c|c|c|}
\hline \multicolumn{3}{|c|}{ Intraspecific Crosses } \\
\hline & Female & Male \\
\hline i) & Clarias angularis & Exotic clarias gariepinus \\
\hline ii) & Exotic clarias gariepinus & Clarias angularis \\
\hline
\end{tabular}

\section{Incubation and Hatching of Eggs}

Incubation and hatching of eggs were done in eight (8) flow through breeding white container, clean mosquito netting materials (eggs collectors) were place in each breeding containers for egg to attach, each cross were duplicated, both the parental and the intraspecific crosses. The fertilized eggs were spread on the netting materials in the breeding containers at temperature of between $26^{\circ} \mathrm{C}-27^{\circ} \mathrm{C}$. At hatching, all the dead eggs, dead hatchlings and live hatchlings were counted in each duplicated containers.

Percentage hatchability of each crosses were calculated using this formula.

\section{$\%$ Hatchability $=\quad$ Total number of hatched eggs $\quad$ X 100 \\ Total number of fertilized egg}

\section{Setting of indoor Experiment and Daily Survival of Hatchlings}

Each treatment was in triplicates. Hundred (100) hatchlings after taken the pooled weight were collected and placed in each flow through container measuring $60 \times 30 \times 30 \mathrm{~cm}^{3}$. The survival of fries in each container per treatment were taken on daily basis for 14 days, while pooled weight, pooled length and final survival were taken on the $14^{\text {th }}$ day. 


\section{Feeding of Larvae}

Three (3) days after hatching, all reserved yolk were completely reabsorbed by the fries. Coppens catco crumble excellent $0.2-0.3 \mathrm{~m}$ were finely grinded and fed to the fries for a period of 14 days. During these periods, measurement such as weight and length of fries were taken on weekly basis.

\section{Statistical Analysis}

The data collected during the experiment were subjected to Analysis of Variance and the means separated with Dunchan multiple range tests for testing treatment means using SPSS Package.

\section{Result and Discussion}

Result

Percentage Hatchability and Survival

Table 1 shows percentage hatchability of Clarias anguilaris and their intraspecific cross reared indoor for 2 weeks. The highest percentage hatchability (52.94\%) was recorded for the parental exotic Clarias gariepinus while the least $(43.99 \%)$ was recorded for parental Clarias angularis. However, the two parental crosses i.e. Clarias anguilaris with male Clarias gariepinus had the best indoor percentage survival of $91.67 \%$ and $70.00 \%$ respectively.

Table 1:Percentage hatchability survival of fry in the crosses involving Clarias anguilaris and exotic hollandis Clarias gariepinus.

\begin{tabular}{|l|l|l|}
\hline Combination & \% Hatchability & \% Survival \\
\hline CA X CA & $43.99^{\mathrm{a}}$ & \\
\hline HCG X HCG & $52.94^{\mathrm{a}}$ & $91.67^{\mathrm{a}}$ \\
\hline CA X HCG & $51.90^{\mathrm{a}}$ & $70.00^{\mathrm{a}}$ \\
\hline HCG X CA & $50.68^{\mathrm{a}}$ & $68.33^{\mathrm{a}}$ \\
\hline
\end{tabular}

a - means column with superscript are not significantly different $(\mathrm{p}<0.05)$

\section{Indoor performance of parental and intraspecific Crosses}

Table 2: shows the growth performance of parental and the intraspecific crosses reared for two weeks. There was significant different $(\mathrm{p}<0.05)$ in respect to initial weight gain of $1.77 \mathrm{~g}$, followed by the intraspecific cross involving female exotic Clarias gariepinus and male Clarias anguilaris recorded the least weight gain $1.43 \mathrm{~g}$.

Table 2 also shows significant difference $(\mathrm{p}<0.05)$ in respect to initial and final length of both the parental and intraspecific crosses reared indoor for 2 weeks. The parental exotic hollandis Clarias gariepinus gave the highest length increase of $0.89 \mathrm{~cm}$ while the least length was recorded for the parental Clarias anguilaris.

Table 2: Growth Performance

\begin{tabular}{|l|l|l|l|l|l|l|}
\hline $\begin{array}{l}\text { Mating } \\
\text { combination }\end{array}$ & $\begin{array}{l}\text { Initial pool } \\
\text { weight }(\mathrm{g})\end{array}$ & $\begin{array}{l}\text { Final pool } \\
\text { weight(g) }\end{array}$ & $\begin{array}{l}\text { Weight } \\
\text { gain(g) }\end{array}$ & $\begin{array}{l}\text { Initial } \\
\text { length(cm) }\end{array}$ & $\begin{array}{l}\text { Final } \\
\text { length(cm) }\end{array}$ & $\begin{array}{l}\text { Length } \\
\text { increase(cm) }\end{array}$ \\
\hline CA X CA & $0.1^{\mathrm{a}}$ & $1.53^{\mathrm{a}}$ & 1.43 & $0.86^{\mathrm{a}}$ & $1.39^{\mathrm{b}}$ & 0.53 \\
\hline HCX HCG & $0.1^{\mathrm{c}}$ & $1.87^{\mathrm{a}}$ & 1.77 & $0.64^{\mathrm{b}}$ & $1.53^{\mathrm{a}}$ & 0.89 \\
\hline CAXHCG & $0.1^{\mathrm{b}}$ & $1.63^{\mathrm{a}}$ & 1.53 & $0.60^{\mathrm{c}}$ & $1.40^{\mathrm{b}}$ & 0.80 \\
\hline HCGXCA & $0.1^{\mathrm{a}}$ & $1.70^{\mathrm{a}}$ & 1.60 & $0.64^{\mathrm{b}}$ & $1.43^{\mathrm{ab}}$ & 0.79 \\
\hline
\end{tabular}

a-c Means column with different superscript are significantly different $(p<0.05)$ 


\section{Discussion}

Catfish hybridization holds a very high potential for the future, a better catfish hybrid is equivalent to a better catfish aquaculture as well as its contribution to global food security. The result of the intraspecific crosses of Clarias angularis and exotic hollandis Clarias gariepinus shows that highest percentage hatchchability of 52.94\% was recorded for pure exotic Clarias gariepinus (HCG x HCG) followed by cross Clarias angularis $\mathrm{x}$ Hollandis Clarias gariepinus ( CA x HCG) of $51.90 \%$, then $50.68 \%$ for Hollandis Clarias gariepinus $x$ Clarias angularis(HCG $\mathrm{x}$ CA) and the least was $43.99 \%$ for pure Clarias angularis. There was no significant different in percentage hatchability, Although there is has been little research work on this area, but the highest percentage hatchability recorded in exotic Hollandis Clarias gariepinus might be due to generic improvement through selective breeding. De Graaf et, al (1995) reported in the average of $28.40 \%$ and $59.1 \%$ percentage hatchability in ordinary Clarias gariepinus.

The highest indoor percentage survival of $91.67 \%$ was recorded for the parental Clarias angularis and the least of $62.33 \%$ was recorded in female exotic hollandis Clarias gariepinus cross with male Clarias angularis. . The highest survival recorded for parental Clarias angularis might be due to its hardness and adaptation to the environment. Olufeagba et, al. (2000) also recorded highest indoor percentage survival of (72.5\%) for Clarias angularis.

The indoor growth performance presented on Table 2 shows that there is no significant differences in the crosses but exotic hollandis Clarias gariepinus performed better in weight $(1.77 \mathrm{~g})$ and length $(0.89 \mathrm{~cm})$. This might also be attributed to genetic improvement, it undergoes over the years in Ireland (Holland) (Akinwande per. Comm.).

The cross involving female exotic Clarias gariepinus and male Clarias angularis performed better with $1.60 \mathrm{~g}$ in weight and $0.79 \mathrm{~cm}$ length increase than female Clarias gariepinus and male Clarias gariepinus of weight $1.53 \mathrm{~g}$ in weight and length increase of $0.80 \mathrm{~cm}$. Although Bondary(1984) reported that hybrids from intraspecific hybridization are superior in growth, food conversion, resistant to disease, reproductive ability and meat quality but improved viability is the most obvious result.

The least indoor growth performance of $1.43 \mathrm{~g}$ was observed in the Clarias anguilaris which also recorded least length increase of $0.53 \mathrm{~cm}$ but gave the highest indoor percentage survival of $91.67 \%$. The highest survival value might translate to better performance if the Clarias anguilaris is genetically improved.

\section{CONCLUSION AND RECOMMENDATION}

\section{CONCLUSION}

The result of Intraspecific hybridization studies carried out on exotic hollandis Clarias gariepinus and Clarias anguilaris strain with the aim of determining the combination with the best hatchability, survival rate and growth performance shows that Male exotic Clarias gariepinus x Female Clarias anguilaris is better because the hybrid has high survival rate, percentage hatchability and length increase close to the pure parental breed and the percentage of growth rate is also close to that of the exotic fish.

\section{RECOMMENDATION}

Since it has been clearly observed form this research work that the two hybrids from the combination of $C$. gariepinus and $C$. angularis has combined the traits of the two parental breed but the cross of Male exotic Clarias gariepinus $\mathrm{x}$ Female Clarias anguilaris is of high side in terms of \% hatchability and survival with no significant difference in the growth performance. Hence it is recommended that male exotic hollandis Clarias gariepinus should be used to cross the female Clarias angularis instead of female exotic hollandis Clarias gariepinus x male Clarias angularis. I also recommend the application of selective breeding for the improvement of our Clarias angularis because of its adaptation to our local environment which is revealed in the value of its survival rate.

\section{REFERENCES}

1. Akinwande (2005): Sequence comparism of partial cytochrome b gene of two colia species . J.

2. Ocean University of china, 4 (1) :85 -88.

3. Aluko, P. O. (1990): Evaluation of hatchability, survival and growth of Clarias anguilaris. World

4. J. Biotechnol., 11: 1662 - 1667.

5. Aluko, P. O., Aremu, A. and Isaah S. (1999): Growth Performance of Intraspecific Hybrids of three strain of $H$ longifilis. NIFFR Annual report 1999 Pp 45 -49 .

6. Andrade-Neto VF, Brandão MG, Stehmann JR, Oliveira LA, Krettli AU (2003). Antimalarial activity of Cinchona-like plants used to treat fever and malaria in Brazil. J. Ethnopharmacol. 87(2-3):253-256.

7. Ayoola, J. (2001): Improved Fish Seed through Biotechnology. A project submitted in partial Fulfillment of the Award of HND at FCFFT, New Bussa. Pp $1-3$.

8. Agnese, J.F., Otenee, Z.J., Gilles, S.(1995): Effect of domestication on generic variability, survival and Growth rate in a tropical Siluriform: Heterobranchus longifils valenciennes

9. 1840. Aquaculture 131:197-204.

10. Bakos, J. and Gorda S.(19995): Genetic improvement of common carp strains using Intraspecific Hybridization. 
Aquacultive Performance Growth and Survival of Selected and wild hhhSelected Channel Catfish. Theor. Appl. Gentic $68.391-395$.

11. Bondary. K. (1984): Reproduction performance growth and survival of selected and wild

12. selected channel catfish. Theor. Appl .Genetic 68. 391-395.

13. Cambray and van derWaal, B.C.W. (2006): Dutch domesticated Clarias with mixed genetic

14. background now used in aquaculture in South Africa, with unpredictable consequences for bioderversit, Afr. J. Aquat.Sci. 31(1):151-153.

15. Chevassus,B.(1979):Hybridization in Salmonids: Result and Perspectives.Aquaculture17,113- 128

16. Dada and Wonah (2003): Fish introduction in Europe with particular reference to its central and

17. Eastern part.Can. J . Fish.Aquat. Sci. 48(Suppl.1):13-23.

18. De Graaf . G. Galemoni F; Banzoussi, B. (1995): Artificial reproduction and fingerling

19. production of the African catfish, clarias gariepinus (Buchel 1822), in reported and

20. protected ponds. Aquaculture research, 1995, 26, 233-242, Editor . S.F. de Graaf

21. and R.J.Roberts. Blackwell science.

22. Dunham, R. A., Malumdark, H. E., Mail, G. Smitherman,(1987), (2001): Review of the status

23. of aquaculture genetic in K.P. Subasinghe, P. Bueno, M.J. Philips; C. Hought's F.

24. and J.R. Arthuriseds, Aquaculture in the third Millennium Technical Proceeding of the Conference on Aquaculture in the third millennium, Bangkok, Thailand, $20-25$ February 137-166, NACA Bangkok and FAO, Rome.

25. Ferris et..al. $(1982,1996,2000,2002)$ : The perpetual oversight of hatchery programmes. Fish.

26. Res.18:19-27.

27. Fujii, (2002): Tracking released Japenese flounder Paralichthys olivacous by Mitochondrial DNA sequence. In: chill, K. (Eds.), Ecology and Aquaculture Species and enhancement of stocks. Proc. $13^{\text {th }}$ US-Japan meeting on aquaculture. Pp 51-53.

28. Husman, E. A and Richter, C.J.J.(1987): Reproduction, Growth, Health Control and Aquaculture potentials of African Catfish Clarrias gariepinus (Burchell, 1822) Neth J.Agric. Sci. 35 (I): 63-66

29. Kuma et.,al.(2004): Reciprocal hybridization between two catfishes H. Fossilis and Clarias

30. Betrachus. Indian J. Exp. Biol., 33:433-433.
31. Madu, C.T. and Aluko P.O. (1999): Hybrid Mudfish Comparative growth and Survival of Hybrid and Initiative Parent proc Biotech Society 1999. Pp 89-94

32. Nlewadin, A.A. (2002): Hybridization Studies in three Clarrid Fishes. Phd Thesis Michael Okpara University of Agriculture Umudike, Nigeria Pp 1.

33. Nwadukwe, F.O. (1995): Fatchery Propagation of five Hybrid groups by Artificial Hybridization of Clarias gariepinus (B) and Heterobranchus Longifilis (Val. Clariidae) using dry powerdered carps pituitary Hormone. Journal of Aquaculture in the Tropics 10, 1-11.

34. Olufeagba, S.O. and Aluko P.O. (1997): Growth and Survival of Triploid H. Longifilis (Vol. 1840) NIFFR Annual report 1979. Pp 102 - 109

35. Olufeagba, S.O., Ladu, B.M.B., Erinle, E.O., Woru, D. Aremu, B; Victor, M and Shuaibu, Y. (2002). Studies of Hatchability, Growth and Survival rate in Hollandis, Heterobranchus longifilis and Claias gariepinus, NIFFR.

36. Oloyede HOB (2005). All for the love of nutrients. The seventy eight inaugural lecture, Library and publication Committee, University of Ilorin.

37. Seagrant (1987): Genetic guidelines for Fisheries Management Seagrant Research Report (17) Published by Minnesota seagrant, University of Minnesota.

38. Smitherman and Dunham (1995): Experimental hybridization

39. Tave, D. (1993): Genetics for hatchery management $\left(2^{\text {nd }}\right.$ edition). A an AVI, New York.

40. Teugel, G.G. (1986): A system revision of the African Species of Genus Clarias (Pisces Claridae) Konin Klijk Museum Voor Middle Africa Tervurea, Belgium. P

41. Teugels and Adriaens (2003): Production of exotic clarias gariepinus fingerlings at varying

42. stocking density in outdoor concrete pond.

43. Venden and Bernsak (1999): in Nlewadim AA200 hybridization studies in three fishes PHD

44. thesis Michael Opara University of Agric, Umudike, Nigeria. Pp 11.

45. Venden Bossiclae and Bersak (1990): Source Book for the Inland Fishery Resources of Africa. 2 GFA. Tech. Paper No 18. 2 pp 411, Rome.

46. Wohlfarth, G.W. (1994): The Unexploited Potential of Tilapia Hybrids in Aquaculture.

47. Aquaculture and Dish Management 25: pp 781 - 788.

48. Zegarac J.P. (2014). The Power of Blueberries Today's Dietitian 16(10):42. 